\title{
The Impact of Firm Leverage on Shareholders' Wealth in Southeast Asia
}

\author{
Deavina Retkaputri1 ${ }^{1, *}$ Zaäfri A. Husodo ${ }^{2}$ \\ ${ }^{1}$ Universitas Indonesia \\ ${ }^{2}$ Universitas Indonesia \\ "Corresponding author. Email: deavina.retkaputri91@ui.ac.id
}

\begin{abstract}
The issue of the firm capital structure continues to be an exciting phenomenon to research. Begins with the development of theories regarding optimal leverage, to the proliferation of research on firms with zero leverage, which are apparently more profitable. This study attempts to identify the impact of firm leverage on shareholders' wealth in Southeast Asian firms between 2009 and 2018 using panel data analysis. Our results show that there is a non-linear relationship between firm leverage and shareholder wealth. Contrary to the suggestion of optimal leverage theory, this non-linear relationship indicates that leverage has a negative relationship to dividend yield up to a certain point, but the relationship turns positive at high debt levels. This implies that managers should consider any increase in the firm leverage, since additional debt does not always increase shareholder wealth. Additionally, our results show that several firm-level and country-level factors significantly correlated with shareholder wealth, such as sales growth, growth opportunity, profitability, cash holdings, asset tangibility, inflation and corporate income tax. Understanding the impact of leverage on shareholders' wealth enhances managers' decisions in capital structure and complements knowledge to investors who would like to increase wealth through dividends.
\end{abstract}

Keywords: Capital structure, optimal leverage, shareholder wealth, dividend yield.

\section{INTRODUCTION}

The capital structure and level of firm debt have been the subject of research in various countries from past to present. Several studies demonstrate the effect of leverage on the firm's value [1]-[6]. However, recent studies highlight a phenomenon regarding the low firm debt level in recent years. Dang [7] establishes that firm debt conservatism in the UK increased from the late 1990 s to the early 2000s. This recent phenomenon is demonstrated by Strebulaev \& Yang [8], who found an interesting fact that firms with zero leverage are more profitable than other firms in the same industry. Saona et al. [9] also support the fact that, on average, one-third of firms in 47 countries have a debt level of below 5\%, and even $18 \%$ of firms do not have debt in their capital structure or so-called zero leverage.

Several studies examine the effect of the leverage level on firm performance. In their research on Taiwanese firms, Cheng \& Tzeng [1] found that levered firms have a higher value than unlevered firms if we ignore financial difficulties. However, if firms consider the costs and benefits of debt, leverage positively affects firm value until it reaches the optimal level of debt. This result is in line with the trade-off theory of capital structure. Lin \& Chang [3] also support optimal debt by finding a debt ratio threshold in Taiwanese firms; hence when the firm's debt ratio exceeds the threshold, it no longer increases firm value. On the contrary, numerous studies have established that firm leverage harms dividend payments to shareholders [10]-[12].

Based on existing studies, there are mixed results regarding the impact of firm leverage. On one side, firm leverage can increase firm value to a certain point. However, it turns out to have a negative impact on dividends distributed to shareholders. Hence, there is a need for clarification on how firm debt level correlates with shareholder wealth as this is one of the primary goals of firms.

This paper focuses on examining the impact of firm leverage on shareholders' wealth in Southeast Asia firms. Shareholders' wealth is measured by dividend yield since dividend payments positively affect shareholder wealth [13]. This research has a significant contribution as this region's economy has a considerable influence on the world economy. Using panel data analysis, our results indicate that there is a non-linear relationship between firm leverage and shareholder wealth. Contrary to the suggestion of optimal leverage theory, this non-linear relationship indicates that leverage has a negative relationship to dividend yield up to a certain point, but the relationship turns positive at high debt levels. Additionally, our results show that several firm-level and country-level factors significantly correlated with shareholder wealth, such as sales 
growth, growth opportunity, profitability, cash holdings, asset tangibility, inflation and corporate income tax.

This result contributes additional knowledge to the firm managers which should consider any increase in the firm leverage since additional debt does not always increase shareholder wealth, and to investors who would like to increase their wealth through dividends; it also complements the existing literature of leverage by exploring gaps identified in previous studies.

We organize the rest of the paper as follows. Section 2 explores the literature review related to this research. Section 3 discusses research methodology. Section 4 presents the result and discussion; the final section 5 concludes the paper.

\section{LITERATURE REVIEW}

\subsection{Theoretical Overview}

The theoretical principles underlying capital structures start from the trade-off theory and pecking order theory. Trade-off theory arises from the model proposed by Modigliani \& Miller [4], which concluded that the composition of a firm's debt and equity does not affect firm value since this value is influenced by net operating income generated from the utilization of the firm's assets. By considering each additional debt's costs and benefits, Modigliani \& Miller [5] argued that firms could identify the optimal debt level. Supporting the trade-off theory, Fischer et al. [14] developed a dynamic capital structure choice model by considering recapitalization costs and bankruptcy costs. His research concludes that the firm has an optimal leverage range and allows the firm's leverage ratio to vary between the upper and lower limits of the target leverage. Firms will adjust their capital structure when the leverage touches the upper or lower limits of their target leverage range.

Pecking order theory assumes asymmetric information between management and investors, which causes no optimal corporate debt ratio. Getting external funding is expensive since outside investors will reduce the stock price when choosing to issue shares [15]. Thus, the firm will prefer internal funding to external. If external funding is needed, firms will use safer instruments first, namely debt, then hybrid securities such as convertible bonds, then perhaps equity as a last resort. Pecking order theory predicts the priority structure and maturity of the debt. The firm will issue debt instruments with a lower information cost before issuing debt instruments with a higher information cost. Alternatively, the firm will maximize short-term debt first before finally issuing long-term debt, and secured debt must be issued first before unsecured debt [16].

Several theories that explain firm dividends are signalling theory and agency cost theory. Signalling theory suggests that the firm's decision to distribute dividends to shareholders is a communication that minimizes information asymmetry among managers and shareholders. Through the distribution of dividends, the firm seems to provide a good signal regarding its current profits to provide reasonable expectations for the firm's future earnings [17], [18]. The greater the profit, it is expected that the dividend given will be more significant. Conversely, firms that pay out smaller dividends expect a decrease in the profits they get. Signalling theory also predicts that dividends will also signal the level of information asymmetry. The higher the asymmetric information, the higher the dividend rate distributed to shareholders [12]. Asquith \& Mullins [19] attests to the view that dividends convey unique and valuable information to investors regarding management's interpretation of the firm's current performance and its prospect. Meanwhile, Hoberg \& Prabhala [20] argued that dividends are also a signal of corporate risk; they suggest that there is a negative relationship between dividends and business risk.

Based on agency cost theory, there are differences in management and shareholders' interests, leading to contravention among shareholders and creditors. This conflict can arise over the distribution of dividends. On the one hand, dividend distribution can reduce agency costs by distributing the firm's free cash flow to shareholders rather than management, spending it on unprofitable investments [21]. However, creditors' interest in obtaining their rights in debt and interest payments is likely to affect when firms choose to pay large dividends to shareholders [12]. Both dividend and debt payments are mechanisms for leveraging a firm's cash flow.

\subsection{Empirical Overview}

Currently, there is no literature that directly proves how leverage affects shareholder wealth. Several studies have attempted to explain the relationship between the firm's capital structure and firm performance or value. Cheng \& Tzeng [1] suggests that debt positively affects firm value until the firm reaches the optimal level of debt when firms consider costs and benefits. This result is in line with Lin \& Chang [3], who found two threshold effects between debt ratios and firm value in Taiwanese firms. An increase in the debt ratio after more than a certain threshold does not provide an increase in firm value. On the other hand, Venugopal et al. [6] provide another fact that the ratio of debt-toequity, the ratio of long-term debt, and short-term debt ratio has a positive correlation with created shareholder value (CSV), while the ratio of total debt has a negative correlation. These various research results illustrate that the effect of leverage on a firm's performance and value varies widely.

One of the financial ratios used to measure shareholder wealth is dividend yield [22]. Prempeh \& 
Odartei-Mills [22] used a sample of firms listed on the Ghana Stock Exchange in 2003-2007 and found a negative relationship between the firm's dividend yield and leverage. This result indicates that the increase in corporate debt does not always provide additional wealth for shareholders. Patra et al. [12] also conducted research on dividends and leverage on non-financial firms in Greece 1993-2007. This study proves that corporate debt negatively relates to dividends using Generalized Method of Moments (GMM).

Using panel data analysis, Jabbouri [11] found that corporate debt is one of the dividends' determinants that negatively affect relationships. Three things can cause this negative relationship. First, firms with debt may make dividend deductions voluntarily or because of pressure from creditors, since the firm must maintain its liquidity and prioritize paying debt before distributing dividends [23]. Second, the firm's high debt ratio causes the firm's risk to rise and increases the cost of funding from external parties, so the firm must maintain retained earnings to maintain stability. Third, dividend payments are no longer crucial because debt for firms plays a role in reducing information asymmetry and agency problems [11]. Several other studies also confirm the firm's negative relationship between leverage and dividends [10], [24]-[27]. Based on the results of previous research on leverage, we hypothesize that leverage exerts a positive impact on shareholders' wealth at a low level, but the relationship becomes negative at high level of leverage.

\section{H1. There is a positive relationship between leverage} and dividend yield.

H2. There is a non-linear relationship between leverage and dividend yield, which indicates an optimal value.

Apart from the firm leverage, several other factors also affect firm dividends, such as firm characteristics and country characteristics. Firm characteristics that affect dividends are profitability, firm size, growth opportunities, liquidity, and sales growth. The increase in the firm's profit positively affects dividend payments [28]. Firms with higher profits can pay higher dividends than firms with lower profits [25], [26], [29], [30]. However, a negative relationship between profitability and dividends was found by Al-Kayed [24] and Kuzucu [27]. Then, firms with a larger size are considered to have more ability to pay dividends than smaller firms [27], [28], [30]-[33]. Al-Malkawi [25] argues that large firms have better access to the capital market to obtain funding more easily than small firms.

Al-Najjar [29] found that firm growth opportunities, as measured using the market-to-book ratio, have a positive relationship to the dividend pay-out ratio. This result shows that growing firms are more likely to pay dividends. However, other research results indicate that the market-to-book ratio indicates a negative relationship with the firm's dividend yield [12], [24], [34], [35]. Payment of cash dividends requires substantial cash from the firm. So, the firm's liquidity is supposed to affect dividends since dividends must be paid in cash [27]. The greater the firm's liquidity, the greater the dividends given to shareholders [11], [12]. On the other hand, Al-Kayed [24] research shows that liquidity has a negative relationship with firm dividends. The growth in firm sales can reduce the dividends given. This can be caused by an increase in sales, which will require an enormous cost so that the firm's ability to pay dividends is reduced [33], [36], [37].

Al-Najjar \& Belghitar [38] conducted observations on non-financial companies in the United Kingdom to explore the simultaneous relationship between corporate cash holdings and dividend policy. They found that the company's cash holdings harm dividends received by shareholders. Al-Najjar [29] suggests that asset tangibility has a negative relationship with company dividend yield. Rajverma et al. [39] found a relationship between dividends, leverage, and average cost of capital that are interrelated on companies in India.

Each country's different conditions and characteristics provide unique business situations for the firm that affect its decision to distribute dividends as a share of wealth for shareholders. Inflation, which is a decrease in the value of money and causes an increase in the price of goods, was found to positively impact dividends [37], [40]. Inflation increases the firm's income in nominal value, giving the firm more capable to pay dividends. The tax paid by the firm on the income earned reduces the firm's income that could be distributed to shareholders through dividends. Several previous studies have shown that high corporate taxes prevent firms from paying high dividends [41]-[43].

\section{RESEARCH METHODOLOGY}

Our initial sample consists of firms listed on respective country exchanges in the Southeast Asia region, including Indonesia, Malaysia, Thailand, Philippines, Vietnam, and Singapore. We excluded financial institutions and banks from these observations as their different accounting practices and relatively greater industry regulations compared to other industries may significantly affect debt and dividend decisions. The final sample consists of 670 non-financial firms for the period from 2009 to 2018 , which represents 6700 firm-year observations.

The variables used in this study are measures of leverage, profitability, firm size, growth opportunities, liquidity, sales growth, cash holdings, asset tangibility and cost of capital as firm-level factors; and inflation and tax as country-level factors. The details are as shown in Table 1. 
Table 1. Variables and Measurements

\begin{tabular}{|c|c|}
\hline Vari & Measurement items \\
\hline $\begin{array}{l}\text { Shareholder Wealth } \\
(D Y)\end{array}$ & $\begin{array}{l}\text { Dividend yield, dividend per share } \\
\text { divided by the stock price at the } \\
\text { beginning of the period. }\end{array}$ \\
\hline Leverage (LTTE) & Long-term Debt-to-Equity Ratio \\
\hline Profitability $(P R O F)$ & $\begin{array}{l}\text { Earnings before interest and tax } \\
\text { divided by total assets. }\end{array}$ \\
\hline Firm Size (SIZE) & $\begin{array}{l}\text { The natural logarithm of total } \\
\text { assets. }\end{array}$ \\
\hline $\begin{array}{l}\text { Growth Opportuni } \\
(\text { GROWTHOPP })\end{array}$ & Marl \\
\hline Liquidity $(L I Q)$ & $\begin{array}{l}\text { Current ratio or current asset } \\
\text { divided by current liabilities. }\end{array}$ \\
\hline vth & $\begin{array}{l}\text { Annual growth rate of the firm's } \\
\text { total sales for a given year } \\
\text { compared to the previous year. }\end{array}$ \\
\hline $\begin{array}{l}\text { ings } \\
\text { LDING) }\end{array}$ & sset. \\
\hline $\begin{array}{l}\text { Asset Tangibility } \\
(T A N G)\end{array}$ & $\begin{array}{l}\text { Fixed assets divided by total } \\
\text { assets. }\end{array}$ \\
\hline Cost of Capital (WACC) & Weighted average cost of capital. \\
\hline Inflation Rate (INF) & $\begin{array}{l}\text { The annual growth rate of the } \\
\text { GDP deflator which shows price } \\
\text { changes in the economy. }\end{array}$ \\
\hline $\begin{array}{l}\text { Corporate Income Tax } \\
(T A X)\end{array}$ & $\begin{array}{l}\text { Country's corporate income tax } \\
\text { rate }\end{array}$ \\
\hline $\begin{array}{l}\text { Dummy Industry } \\
(d I N D)\end{array}$ & $\begin{array}{l}1 \text { for manufacturing firm, } 0 \\
\text { otherwise }\end{array}$ \\
\hline $\begin{array}{l}\text { Dummy State-Owned } \\
\text { Enterprise }(d S O E)\end{array}$ & $\begin{array}{l}1 \text { for state-owned enterprise firm, } \\
0 \text { otherwise }\end{array}$ \\
\hline $\begin{array}{l}\text { Dummy Country } \\
(d \text { Country })\end{array}$ & $\begin{array}{l}1 \text { for each country dummy, } 0 \\
\text { otherwise }\end{array}$ \\
\hline
\end{tabular}

To examine the non-linearity relationship between the leverage and shareholder wealth, the square term of leverage is used in this study as in the model used by Guney et al. [44], Ly-Dai [45], and Tarverdi [46]. This study applies the fixed effect and random effect model for a robustness check. The following is the main regression model:

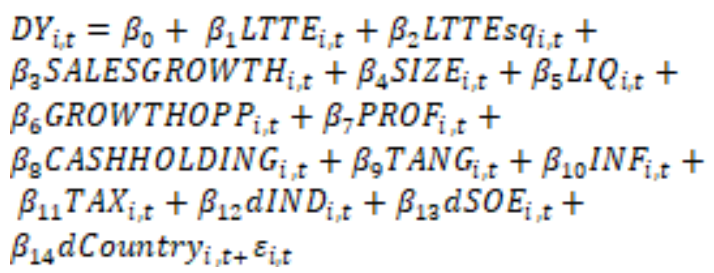

For robustness check purposes, we also analyse the relationship between total debt ratio (TDTE) and shortterm debt ratio (STTE) in our analysis.

\section{RESULTS AND DISCUSSION}

\subsection{Descriptive Analysis}

Table 2 describes the descriptive statistics for the main variables used in our analysis. The average dividend yield $(D Y)$ obtained by shareholders, our dependent variable, is $3.3 \%$. The average ratio of longterm debt-to-equity (LTTE), our main independent variable, is $45.2 \%$. Table 3 reports the mean value of each variable for each country. The country with the highest long-term debt ratio was Thailand with 57.24\%. Then, the next position is the Philippines, Vietnam, Indonesia, Singapore, and Malaysia. However, countries with the highest leverage do not guarantee to provide the largest dividend yield. The country with the highest dividend yield is Vietnam with $5.59 \%$. Meanwhile, Thailand ranks the fifth largest dividend yield after Vietnam, Malaysia, Singapore and Indonesia.

We conducted an initial analysis of the relationship between firm leverage and dividend yield using a bar chart. Figure 1 indicates the relationship between the dividend yield and the debt level which is not linear. The first chart shows that there is an indication of

Table 2. Descriptive statistics for main variables

\begin{tabular}{|l|r|r|r|r|}
\hline \multicolumn{1}{|c|}{ Variables } & \multicolumn{1}{c|}{ Mean } & \multicolumn{1}{c|}{$\begin{array}{l}\text { Std. } \\
\text { Dev }\end{array}$} & \multicolumn{1}{c|}{ Min } & \multicolumn{1}{c|}{ Max } \\
\hline DY & 0.033 & 0.031 & 0.000 & 0.120 \\
\hline LTTE & 0.452 & 0.781 & 0.000 & 9.136 \\
\hline TDTE & 0.865 & 1.153 & 0.000 & 13.252 \\
\hline STTE & 0.405 & 0.563 & 0.000 & 4.371 \\
\hline SALESGROWTH & 0.142 & 0.571 & -7.698 & 8.121 \\
\hline SIZE & 14.989 & 1.797 & 11.261 & 18.739 \\
\hline LIQ & 1.757 & 1.053 & 0.000 & 4.886 \\
\hline GROWTHOPP & 1.321 & 1.641 & 0.023 & 13.361 \\
\hline PROF & 0.059 & 0.058 & -0.102 & 0.220 \\
\hline CASHHOLDING & 0.005 & 0.068 & -0.217 & 0.224 \\
\hline TANG & 0.057 & 0.052 & 0.000 & 0.194 \\
\hline INF & 0.324 & 0.232 & 0.000 & 0.802 \\
\hline TAX & 0.028 & 0.033 & -0.052 & 0.113 \\
\hline
\end{tabular}

optimal leverage in long-term debt. The relationship between long-term debt and dividend yield is positive at low debt ratio, however, tends to be negative at high debt ratio. Meanwhile, the relationship for the total debt and long-term debt ratio with the dividend yield shows a negative relationship at low debt levels, but at high debt levels, the dividend yield tends to increase.

Figure 2 shows that based on long-term debt ratio, there are indications of optimal leverage in Indonesia. Meanwhile, other countries have different trends. In the Philippines, the relationship between debt and dividend yield tends to be positive, contrarily, in 
Table 3. Descriptive statistics for the main variables each country

\begin{tabular}{|l|r|r|r|r|r|r|}
\hline \multicolumn{1}{|c|}{ Variables } & \multicolumn{1}{c|}{ Indonesia } & \multicolumn{1}{c|}{ Malaysia } & \multicolumn{1}{c|}{ Thailand } & \multicolumn{1}{c|}{ Philippines } & \multicolumn{1}{c|}{ Vietnam } & \multicolumn{1}{c|}{ Singapore } \\
\hline DY & 0.0260 & 0.0306 & 0.0245 & 0.0196 & 0.0559 & 0.0285 \\
\hline LTTE & 0.4910 & 0.3193 & 0.5724 & 0.5511 & 0.5489 & 0.4296 \\
\hline TDTE & 0.8757 & 0.6212 & 1.1317 & 0.8613 & 1.3031 & 0.7697 \\
\hline STTE & 0.3824 & 0.3003 & 0.5353 & 0.3102 & 0.7370 & 0.3290 \\
\hline SALESGROWTH & 0.1159 & 0.1115 & 0.1668 & 0.2107 & 0.1781 & 0.1372 \\
\hline SIZE & 15.6340 & 14.8792 & 14.9761 & 16.1780 & 13.4323 & 15.5757 \\
\hline LIQ & 1.6359 & 1.9586 & 1.6021 & 1.6487 & 1.4740 & 1.7930 \\
\hline GROWTHOPP & 2.0233 & 1.1963 & 2.2627 & 2.0011 & 0.8494 & 1.1562 \\
\hline PROF & 0.0857 & 0.0616 & 0.0649 & 0.0585 & 0.0682 & 0.0372 \\
\hline CASHHOLDING & 0.0736 & 0.0561 & 0.0440 & 0.0443 & 0.0369 & 0.0714 \\
\hline TANG & 0.3888 & 0.3453 & 0.4102 & 0.2949 & 0.3426 & 0.2532 \\
\hline INF & 0.0557 & 0.0185 & 0.0200 & 0.0248 & 0.0565 & 0.0145 \\
\hline TAX & 0.2530 & 0.2460 & 0.2330 & 0.3000 & 0.2290 & 0.1710 \\
\hline Total Firms & 68 & 241 & 19 & 57 & 117 & 160 \\
\hline Total Observations & 680 & 2410 & 190 & & & 1680 \\
\hline
\end{tabular}

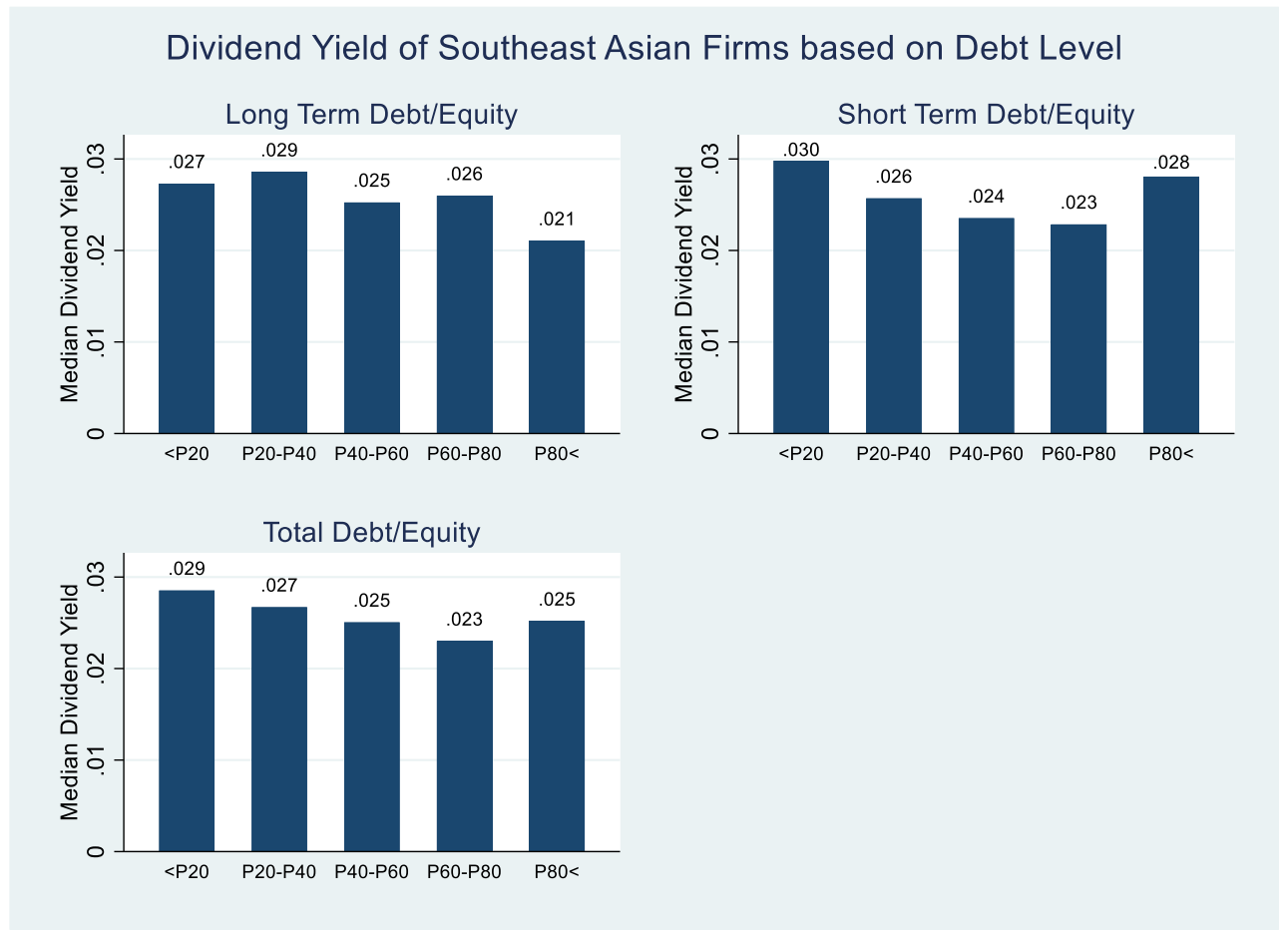

Figure 1. Dividend Yield of Southeast Asian Firms based on Debt Level

Malaysia the relationship tends to be negative. Figure 3 shows the relationship between leverage and dividend yield between sectors. Sectors such as construction, manufacturing, real estate \& leasing, and retail trade have optimal leverage levels. Meanwhile, trends in other sectors are quite diverse. Based on these figures, we know that the relationship between the firm leverage and shareholders' wealth varies between countries and sectors.

\subsection{Regression Analysis}

In the regression test, the dependent variable used is dividend yield as a proxy for shareholder wealth. As for the main independent variable, we used the ratio of debt-to-equity of the company. In the first model, we used the ratio of long-term debt-to-equity (LTTE) as a proxy for the firm's leverage. In the second model used total debt-to-equity (TDTE) and the third model used short-term debt-to-equity $(S T T E)$. In the regression using the random effects model, we used dummy variables for industry, state-owned companies, and the country.

Table 4 presents the comparison of the regression results in the fixed effects and random effects models. It shows that the firm leverage has a negative relationship with shareholder wealth. We only found the significant negative relationship in long-term debt. This means that the greater the firm's long-term debt, the lower the 
shareholder's wealth. However, long-term debt and dividend yield has a non-linear relationship as shown by a positive coefficient of leverage squared variable. This shows that there is a turning point where the negative relationship between long-term debt and dividend yield turns out to be positive. Short-term debt ratio does not have a significant relationship with dividend yield. dividend yield is in line with previous studies conducted by Al-Kayed [24], Al-Twaijry [10], and Jabbouri [11]. Several control variables that have a significant relationship to dividend yield are sales growth, growth opportunity (GROWTHOPP), profitability (PROF), cash holdings, asset tangibility (TANG), inflation (INF) and tax.

The negative relationship between leverage and

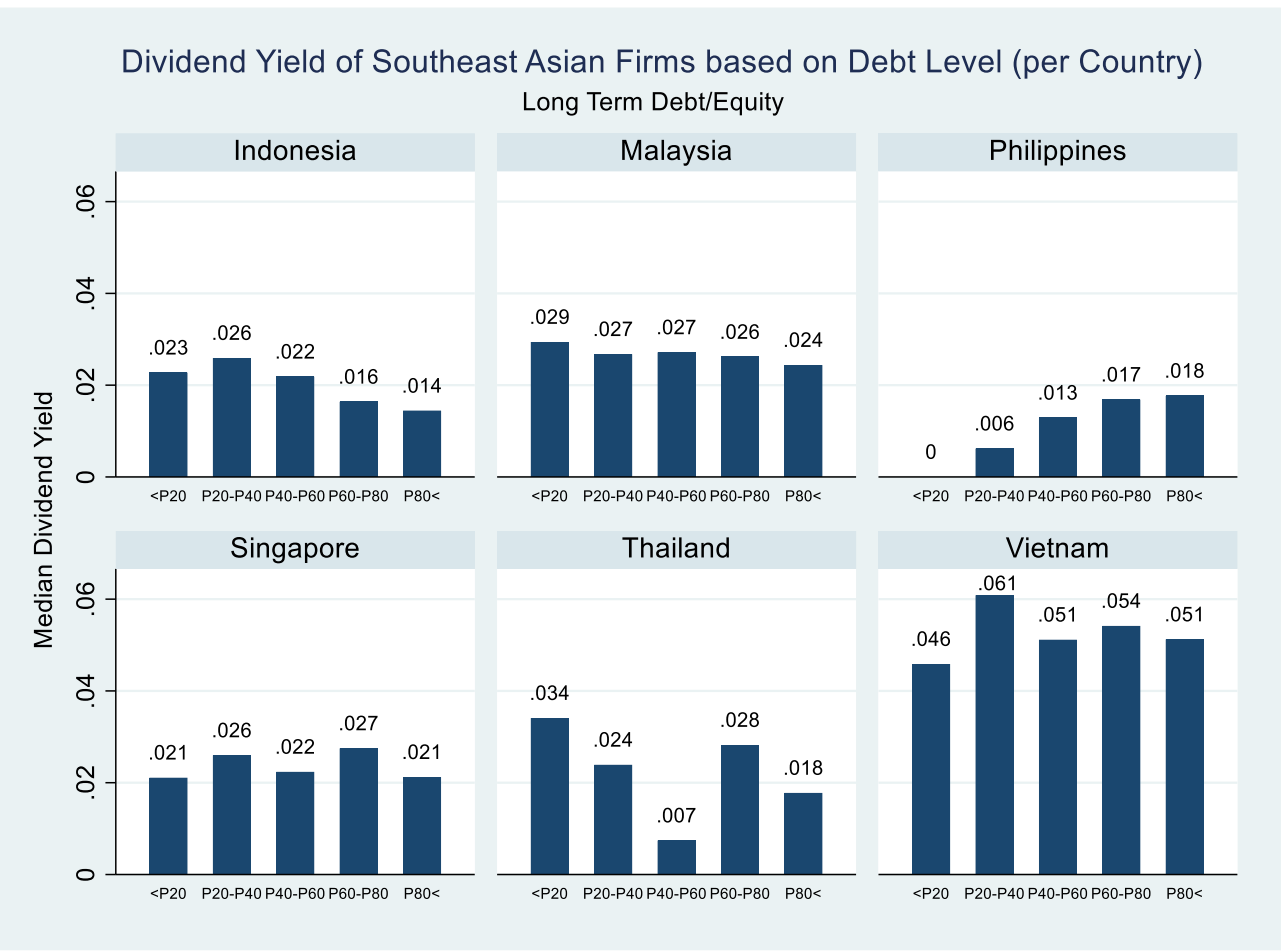

Figure 3. Dividend Yield of Southeast Asian Firms based on Debt Level (per Country)

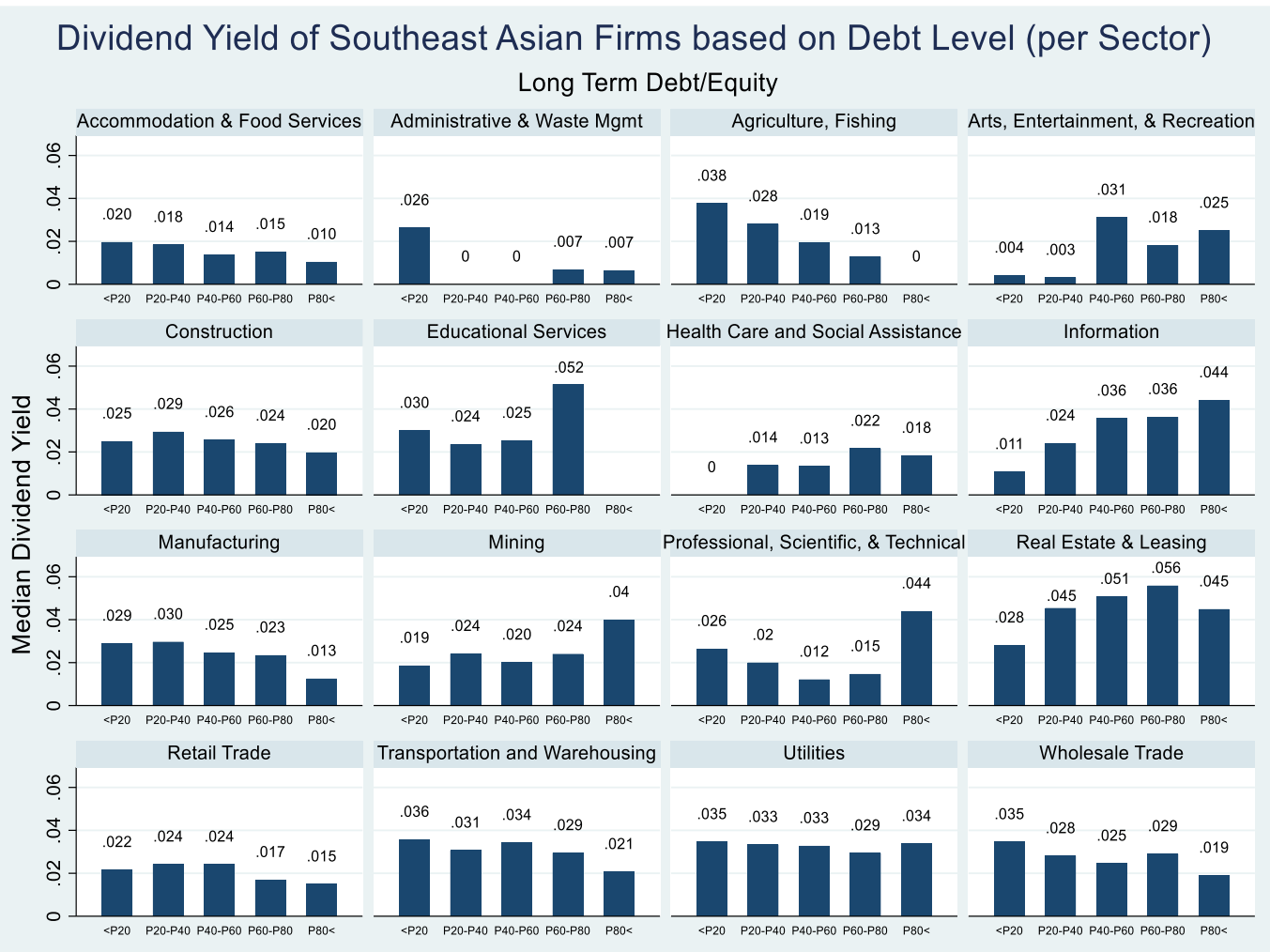

Figure 2. Dividend Yield of Southeast Asian Firms based on Debt Level (per Sector) 
We analysed separately the sample of companies in 2015-2018 using an additional variable, namely the weighted average cost of capital (WACC). The addition of this variable is used as a robustness check since the cost of capital is related to the level of corporate debt. With a high level of debt, the company's capital costs tend to be high. Table 5 shows a comparison of the results in the fixed effects and random effects models. In 2015-2018 period, consistent with the previous regression results, the relationship between long-term debt and dividend yield is negative, so the greater the level of leverage the lower the dividend yield obtained by shareholders. The relationship between WACC and dividend yield shows that the company with the greater the cost of capital, the smaller the wealth that will be given to shareholders.

Furthermore, we conducted a robustness test with a linearity test using a sample of each country. Table 6 shows that the relationship between long-term debt-toequity and dividend yield in all country is negative, except for Vietnam. This sign implies that the greater the leverage, the lower the shareholder wealth provided by the company. A significant negative relationship exists in firms, especially in the Philippines, Indonesia, and Thailand. Additionally, the non-linear relationship is shown by the coefficient estimation of the square value of the debt ratio. In all countries other than Vietnam, the leverage squared is positive, but only significant in the Philippines, Indonesia, and Thailand. This means that there is a minimum point of the negative relationship between debt and dividend yield. So that at a certain point the relationship changes from negative to positive where the greater the firm leverage, the greater dividend yield.

\subsection{Discussion}

The results of the descriptive analysis indicate a non-linear relationship between firm leverage and dividend yield. These preliminary results are supported by a regression test that used the long-term debt-toequity ratio as a measure of leverage. This non-linear relationship explains that leverage has a negative relationship to dividend yield up to a certain point, but the relationship turns positive at high debt levels. The negative relationship can occur because indebted firms reduce dividends voluntarily, pressure from creditors makes companies prioritize their liquidity and debt payments before dividend distribution [12], [23].

However, the indication of minimum turning point is not in line with the hypothesis that Southeast Asian firms have an indication of optimal leverage, as proposed by the trade-off theory. Our result shows that an increase in the leverage does not always provide additional wealth for shareholders because the relationship between these two variables is negative. However, this negative relationship has a minimum point that allows companies with high debt levels to provide more wealth to shareholders. Based on descriptive analysis per sector, this result could due to there are certain sectors that tend to provide higher wealth when the long-term debt ratio is high. Among them are information sector companies; educational services; mining; and professional, scientific, \& technical service.

\section{CONCLUSION}

We have investigated the relationship between firm leverage and shareholder wealth using firm-level data in several Southeast Asian countries. This paper analyses of a non-linear relationship between leverage and shareholder wealth. The main result indicates that relationship between firm leverage and shareholder wealth is negative at low debt levels, but changes to positive at high debt levels. This phenomenon is not in line with the hypothesis that Southeast Asian firms have an indication of optimal leverage, as proposed by the trade-off theory. We argue that this is due to different relationship patterns and variability in each country and firm sector. There are certain sectors that provide higher wealth when the long-term debt ratio is high.

We also find that several firm-level factors have a significant relationship with shareholder wealth, such as sales growth, growth opportunity, profitability, cash holdings, and asset tangibility. Additionally, countrylevel factors such as inflation and corporate income tax rate also correlate with shareholder wealth. With these results, we recommend managers in Southeast Asia to consider any increase in the firm leverage since additional debt does not always increase shareholder wealth.

This study focuses on measuring shareholder wealth through dividends provided with limited country-level control variables. Our suggestion for future research is to add another variable that can explain better the variability of shareholder wealth between countries. Additionally, research that focuses on differences between sectors can also explain the variability of shareholder wealth.

\section{AUTHORS' CONTRIBUTIONS}

Conceptualization: Z.H.; methodology: D.R. and Z.H.; validation: D.R. and Z.H.; formal analysis: D.R. and Z.H.; writing-original draft preparation: D.R. 
Table 4. Regression Test Results for 2009-2018 Samples

Dependent Variable: Dividend Yield

Observations: 6700

Robust Standard Errors

\begin{tabular}{|c|c|c|c|c|c|c|}
\hline & \multicolumn{3}{|c|}{ Fixed Effects } & \multicolumn{3}{|c|}{ Random Effects } \\
\hline & Model 1 & Model 2 & Model 3 & Model 1 & Model 2 & Model 3 \\
\hline LTTE & $-0.003 * *$ & & & $-0.003 * *$ & & \\
\hline LTTEsq & $0.000 *$ & & & $0.000^{*}$ & & \\
\hline TDTE & & $-0.003^{*}$ & & & -0.002 & \\
\hline TDTEsq & & 0.000 & & & 0.000 & \\
\hline STTE & & & -0.001 & & & -0.001 \\
\hline STTEsq & & & -0.000 & & & -0.000 \\
\hline SALESGROWTH & $-0.002 * *$ & $-0.002 * *$ & $-0.002 * *$ & $-0.002 * * *$ & $-0.002 * * *$ & $-0.002 * * *$ \\
\hline SIZE & 0.000 & 0.000 & 0.000 & $0.001 *$ & $0.001 *$ & 0.000505 \\
\hline LIQ & $0.001 * *$ & $0.001 *$ & 0.001 & 0.001 & 0.000 & 0.000 \\
\hline GROWTHOPP & $-0.003 * * *$ & $-0.003 * * *$ & $-0.003 * * *$ & $-0.003 * * *$ & $-0.003 * * *$ & $-0.003 * * *$ \\
\hline PROF & $0.035^{* * *}$ & $0.034 * * *$ & $0.034 * * *$ & $0.063 * * *$ & $0.062 * * *$ & $0.062 * * *$ \\
\hline CASHHOLDING & $-0.036 * * *$ & $-0.036^{* * *}$ & $-0.035 * * *$ & $-0.025 * * *$ & $-0.025 * * *$ & $-0.024 * * *$ \\
\hline TANG & $-0.017 * * *$ & $-0.018 * * *$ & $-0.019 * * *$ & $-0.010^{* * *}$ & $-0.011 * * *$ & $-0.011 * * *$ \\
\hline INF & $0.055^{* * *}$ & $0.055^{* * *}$ & $0.054 * * *$ & $0.054 * * *$ & $0.054 * * *$ & $0.053 * * *$ \\
\hline TAX & $0.152 * * *$ & $0.153^{* * *}$ & $0.143^{* * *}$ & $0.151 * * *$ & $0.150 * * *$ & $0.145^{* * *}$ \\
\hline dIND & & & & -0.002 & -0.002 & -0.002 \\
\hline dSOE & & & & -0.001 & -0.001 & -0.000 \\
\hline dIndonesia & & & & -0.006 & -0.006 & -0.006 \\
\hline dMalaysia & & & & 0.000 & 0.000 & 0.001 \\
\hline dPhilippines & & & & $-0.018 * * *$ & $-0.018 * * *$ & $-0.017 * * *$ \\
\hline dVietnam & & & & $0.026 * * *$ & $0.026 * * *$ & $0.026^{* * *}$ \\
\hline dSingapore & & & & $0.011^{* *}$ & $0.010^{* *}$ & $0.010^{* *}$ \\
\hline _cons & 0.003 & 0.003 & 0.011 & -0.014 & -0.012 & -0.009 \\
\hline$R$-sq within & 0.048 & 0.048 & 0.048 & 0.044 & 0.044 & 0.043 \\
\hline$R$-sq overall & 0.022 & 0.019 & 0.025 & 0.170 & 0.169 & 0.170 \\
\hline
\end{tabular}


Table 5. Regression Test Results for 2015-2018 Samples

\begin{tabular}{|c|c|c|c|c|c|c|}
\hline \multicolumn{7}{|c|}{$\begin{array}{l}\text { Dependent Variable: Dividend Yield } \\
\text { Observations: } 2680 \\
\text { Robust Standard Errors }\end{array}$} \\
\hline & \multicolumn{3}{|c|}{ Fixed Effects } & \multicolumn{3}{|c|}{ Random Effects } \\
\hline & Model 1 & Model 2 & Model 3 & Model 1 & Model 2 & Model 3 \\
\hline LTTE & $-0.004 *$ & & & $-0.005 * * *$ & & \\
\hline LTTEsq & $0.000 *$ & & & $0.001 * *$ & & \\
\hline TDTE & & -0.002 & & & $-0.003 * *$ & \\
\hline TDTEsq & & 0.000 & & & 0.000 & \\
\hline STTE & & & 0.001 & & & -0.002 \\
\hline STTEsq & & & -0.000 & & & 0.000 \\
\hline SALESGROWTH & -0.001 & -0.001 & -0.001 & -0.001 & -0.001 & -0.001 \\
\hline SIZE & 0.003 & 0.003 & 0.002 & $0.002 * * *$ & $0.002 * * *$ & $0.002 * * *$ \\
\hline LIQ & 0.001 & 0.000 & 0.000 & 0.000 & 0.000 & 0.000 \\
\hline GROWTHOPP & $-0.003 * * *$ & $-0.003 * * *$ & $-0.003 * * *$ & $-0.002 * * *$ & $-0.002 * * *$ & $-0.002 * * *$ \\
\hline PROF & -0.025 & $-0.026^{*}$ & -0.024 & 0.020 & 0.019 & 0.021 \\
\hline CASHHOLDING & -0.006 & -0.005 & -0.004 & 0.000 & 0.002 & 0.003 \\
\hline TANG & -0.009 & -0.011 & -0.012 & -0.003 & -0.005 & -0.005 \\
\hline WACC & -0.018 & -0.020 & -0.018 & $-0.041^{*}$ & $-0.045^{*}$ & -0.039 \\
\hline INF & 0.022 & 0.024 & 0.025 & 0.025 & 0.028 & 0.029 \\
\hline TAX & 0.083 & 0.083 & 0.076 & 0.092 & 0.090 & 0.083 \\
\hline dIND & & & & $-0.004 *$ & -0.003 & -0.003 \\
\hline dSOE & & & & -0.006 & -0.005 & -0.005 \\
\hline dIndonesia & & & & -0.011 & -0.011 & -0.010 \\
\hline dMalaysia & & & & -0.008 & -0.008 & -0.007 \\
\hline dPhilippines & & & & -0.019 & -0.019 & -0.018 \\
\hline dVietnam & & & & $0.019 * * *$ & $0.020 * * *$ & $0.019^{* * *}$ \\
\hline dSingapore & & & & -0.002 & -0.002 & -0.002 \\
\hline _cons & -0.020 & -0.021 & -0.010 & -0.016 & -0.011 & -0.008 \\
\hline$R$-sq within & 0.023 & 0.022 & 0.021 & 0.014 & 0.013 & 0.012 \\
\hline$R$-sq overall & 0.000 & 0.000 & 0.000 & 0.114 & 0.113 & 0.109 \\
\hline
\end{tabular}




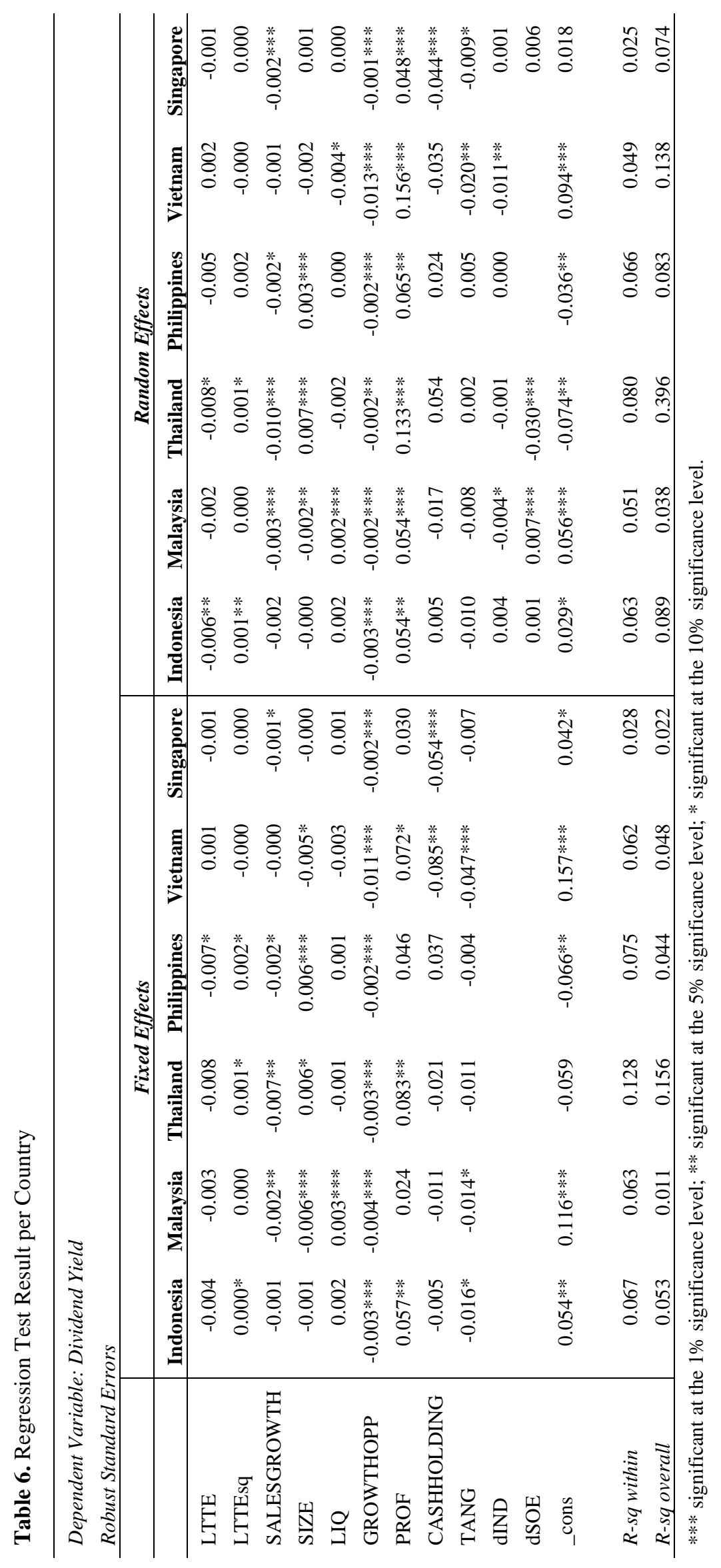




\section{REFERENCES}

[1] M. C. Cheng and Z. C. Tzeng, "Effect of leverage on firm market value and how contextual variables influence this relationship," Rev. Pacific Basin Financ. Mark. Policies, vol. 17, no. 1, pp. 1-63, 2014, doi: 10.1142/S0219091514500040.

[2] E. F. Fama and K. R. French, "Testing Trade-Off and Pecking Order Predictions About Dividends and Debt," Rev. Financ. Stud., vol. 15, no. 1, pp. 1-33, 2002, doi: 10.1093/rfs/15.1.1.

[3] F. L. Lin and T. Chang, "Does debt affect firm value in Taiwan? a panel threshold regression analysis," Appl. Econ., vol. 43, no. 1, pp. 117-128, 2011, doi: 10.1080/00036840802360310.

[4] F. Modigliani and M. H. Miller, "The American Economic Review," Am. Econ. Rev., vol. 48, no. 3, pp. 261-297, 1958, doi: 10.1257/aer.103.1.i.

[5] F. Modigliani and M. H. Miller, "Corporate Income Taxes and the Cost of Capital: A Correction," Am. Econ. Rev., vol. 53, no. 3, pp. 433-443, 1963.

[6] M. Venugopal, Bhanu Prakash Sharma G, and Ravindar Reddy M, "Impact of Capital Structure on Shareholder Value in Indian Pharmaceutical Industry: An Empirical Approach Through Created Shareholder Value," Glob. Bus. Rev., vol. 19, no. 5, pp. 1290-1302, 2018, doi: $10.1177 / 0972150918788741$.

[7] V. A. Dang, "An empirical analysis of zeroleverage firms: New evidence from the UK," Int. Rev. Financ. Anal., vol. 30, pp. 189-202, 2013, doi: 10.1016/j.irfa.2013.08.007.

[8] I. A. Strebulaev and B. Yang, "The mystery of zero-leverage firms," J. financ. econ., vol. 109, no. 1, pp. 1-23, 2013, doi: 10.1016/j.jfineco.2013.02.001.

[9] P. Saona, E. Vallelado, and P. San Martín, "Debt, or not debt, that is the question: A Shakespearean question to a corporate decision," J. Bus. Res., vol. 115, no. September, pp. 378-392, 2020, doi: 10.1016/j.jbusres.2019.09.061.

[10] A. A. Al-Twaijry, "Dividend policy and payout ratio: evidence from the Kuala Lumpur stock exchange," J. Risk Financ., vol. 8, no. 4, pp. 349363, 2007, doi: 10.1108/15265940710777306.

[11] I. Jabbouri, "Determinants of corporate dividend policy in emerging markets: Evidence from MENA stock markets," Res. Int. Bus. Financ., vol. 37, pp. 283-298, 2016, doi: 10.1016/j.ribaf.2016.01.018.
[12] T. Patra, S. Poshakwale, and K. Ow-Yong, "Determinants of corporate dividend policy in Greece," Appl. Financ. Econ., vol. 22, no. 13, pp. 1079-1087, 2012, doi: 10.1080/09603107.2011.639734.

[13] K. Farrukh, S. Irshad, M. Shams Khakwani, S. Ishaque, and N. Ansari, "Impact of dividend policy on shareholders wealth and firm performance in Pakistan," Cogent Bus. Manag., vol. 4, no. 1, 2017, doi: 10.1080/23311975.2017.1408208.

[14] E. O. Fischer, R. Heinkel, and J. Zechner, "American Finance Association Dynamic Capital Structure Choice: Theory and Tests," J. Finance, vol. 44, no. 1, pp. 19-40, 1989, [Online]. Available: https://www.jstor.org/stable/2328273.

[15] S. C. Myers, "The Capital Structure Puzzle," J. Finance, vol. 39, no. 3, pp. 575-592, 1984, doi: 10.1111/j.1540-6261.1984.tb03646.x.

[16] M. Z. Frank and V. K. Goyal, Testing the pecking order theory of capital structure, vol. 67, no. 2. 2003.

[17] S. Bhattacharya, "Nondissipative Signaling Structures and Dividend Policy," Q. J. Econ., vol. 95, no. 1, pp. 1-24, 1980, doi: 10.1017/CBO9781107415324.004.

[18] M. H. Miller and R. Kevin, "Dividend Policy under Asymmetric Information," J. Finance, vol. 40, no. 4, pp. 1031-1051, 1985.

[19] P. Asquith and D. W. Mullins, "The Impact of Initiating Dividend Payments on Shareholders ' Wealth,” J. Bus., vol. 56, no. 1, pp. 77-96, 1983.

[20] G. Hoberg and N. R. Prabhala, "Disappearing dividends, catering, and risk," Rev. Financ. Stud., vol. 22, no. 1, pp. 79-116, 2009, doi: 10.1093/rfs/hhn073.

[21] M. Jensen, “American Economic Association Agency Costs of Free Cash Flow , Corporate Finance, and Takeovers," Am. Econ. Rev., vol. 76, no. 2, pp. 323-329, 1986.

[22] K. B. Prempeh and E. Odartei-Mills, "Corporate Governance Structure and Shareholder Wealth Maximization," Perspect. Innov. Econ. Bus., vol. 15, no. 1, pp. 1-30, 2015, doi: http://dx.doi.org/10.15208/pieb.2015.01.

[23] T. Afza, "Do Mature Companies Pay More Dividends? Evidence from Pakistani Stock Market," Mediterr. J. Soc. Sci., vol. 2, no. 2, pp. 152-161, 2011.

[24] L. T. Al-Kayed, "Dividend payout policy of Islamic vs conventional banks: case of Saudi 
Arabia," Int. J. Islam. Middle East. Financ. Manag., vol. 10, no. 1, pp. 117-128, 2017, doi: 10.1108/IMEFM-09-2015-0102.

[25] H.-A. N. Al-Malkawi, "Determinants of Corporate Dividend Policy in Jordan: An Application of the Tobit Model," J. Econ. Adm. Sci., vol. 23, no. 2, pp. 44-70, 2007.

[26] G. A. Bokpin, “Ownership structure, corporate governance and dividend performance on the Ghana Stock Exchange," J. Appl. Account. Res., vol. 12, no. 1, pp. 61-73, 2011, doi: 10.1108/09675421111130612.

[27] N. Kuzucu, "Determinants of Dividend Policy: A Panel Data Analysis for Turkish Listed Firms," Int. J. Bus. Manag., vol. 10, no. 11, p. 149, 2015, doi: 10.5539/ijbm.v10n11p149.

[28] C. A. Anjana and P. Balasubramanian, "Determinants of dividend policy: A study of selected listed firms in National Stock Exchange," Int. J. Appl. Bus. Econ. Res., vol. 15, no. 4, pp. 101-116, 2017.

[29] B. Al-Najjar, "The inter-relationship between capital structure and dividend policy: Empirical evidence from jordanian data," Int. Rev. Appl. Econ., vol. 25, no. 2, pp. 209-224, 2011, doi: $10.1080 / 02692171.2010 .483464$

[30] M. V. Amuktha and R. Nair, "Corporate social responsibility and shareholder wealth-"evidence from indian manufacturing sector".," Int. J. Innov. Technol. Explor. Eng., vol. 8, no. 8, pp. 33353340, 2019.

[31] H. L. Choy, F. A. Gul, and J. Yao, "Does political economy reduce agency costs? Some evidence from dividend policies around the world," $J$. Empir. Financ., vol. 18, no. 1, pp. 16-35, 2011, doi: 10.1016/j.jempfin.2010.10.001.

[32] E. F. Fama and K. R. French, "Disappearing Dividends: Changing Firm Characteristics or Lower Propensity to Pay?," J. Appl. Corp. Financ., vol. 14, no. 1, pp. 67-80, 2001.

[33] V. Subramaniam and S. Wasiuzzaman, "Corporate diversification and dividend policy: empirical evidence from Malaysia," J. Manag. Gov., vol. 23, no. 3, pp. 735-758, 2019, doi: 10.1007/s10997018-9440-x.

[34] N. J. Dewasiri, W. B. Yatiwelle Koralalage, A. Abdul Azeez, P. G. S. A. Jayarathne, D. Kuruppuarachchi, and V. A. Weerasinghe, "Determinants of dividend policy: evidence from an emerging and developing market," Manag. Financ., 2019, doi: 10.1108/MF-09-2017-0331.

[35] K. M. Y. Lai, W. Saffar, X. (Kevin) Zhu, and Y. Liu, "Political institutions, stock market liquidity and firm dividend policy: Some international evidence," J. Contemp. Account. Econ., vol. 16, no. 1, p. 100180, 2020, doi: 10.1016/j.jcae.2019.100180

[36] A. Gill, N. Biger, and R. Tibrewala, "Determinants of Dividend Payout Ratios: Evidence from United States," Open Bus. J., vol. 3, no. 1, pp. 8-14, 2010, doi: 10.2174/1874915101003010008.

[37] A. Kurniasih, H. Siregar, R. Sembel, and N. A. Achsani, "The determinant of dividend payout policy in the emerging market of Indonesia: Internal versus external factors," Research Journal of Applied Sciences, vol. 9, no. 7. pp. 382-388, 2014, doi: 10.3923/rjasci.2014.382.388.

[38] B. Al-Najjar and Y. Belghitar, "Corporate Cash Holdings and Dividend Payments: Evidence from Simultaneous Analysis," Manag. Decis. Econ., vol. 32, no. 4, pp. 231-241, 2011, doi: 10.1002/mde. 1529 .

[39] A. K. Rajverma, R. Arrawatia, A. K. Misra, and A. Chandra, "Ownership structure influencing the joint determination of dividend, leverage, and cost of capital," Cogent Econ. Financ., vol. 7, no. 1, 2019, doi: 10.1080/23322039.2019.1600462.

[40] T. Basse and S. Reddemann, "Inflation and the dividend policy of US firms," Manag. Financ., vol. 37, no. 1, pp. 34-46, 2011, doi: $10.1108 / 03074351111092139$.

[41] M. Amidu and J. Abor, "Determinants of dividend payout ratios in Ghana," J. Risk Financ., vol. 7, no. 2, pp. 136-145, 2006, doi: $10.1108 / 15265940610648580$.

[42] A. Arif and F. Akbar, "Determinants of Dividend Policy: A Sectoral Analysis from Pakistan," Int. J. Bus. Behav. Sci., vol. 3, no. 9, pp. 16-33, 2013.

[43] K. M. Casey and R. N. Dickens, "The effects of tax and regulatory changes on commercial bank dividend policy," Q. Rev. Econ. Financ., vol. 40, no. 2, pp. 279-293, 2000, doi: 10.1016/s10629769(99)00051-4.

[44] Y. Guney, A. Ozkan, and N. Ozkan, "International evidence on the non-linear impact of leverage on corporate cash holdings," J. Multinatl. Financ. Manag., vol. 17, no. 1, pp. 45-60, 2007, doi: 10.1016/j.mulfin.2006.03.003.

[45] H. Ly-Dai, "Non-linear pattern of international capital flows," Rev. World Econ., vol. 155, no. 3, pp. 575-600, 2019, doi: 10.1007/s10290-01900349-y.

[46] Y. Tarverdi, "Aspects of Governance and CO 2 Emissions: A Non-linear Panel Data Analysis," Environ. Resour. Econ., vol. 69, no. 1, pp. 167194, 2018, doi: 10.1007/s10640-016-0071-x. 